\title{
Impact of public and private sector external debt on economic growth: the case of Portugal
}

\author{
Jorge Silva ${ }^{1}[$
}

Received: 14 October 2019 / Revised: 24 May 2020 / Accepted: 15 July 2020 /

Published online: 10 September 2020

(c) Eurasia Business and Economics Society 2020

\begin{abstract}
External debt may affect economic growth differently among countries. We assess the effect of the Portuguese external debt for the 1999-2019 period. Portugal had the highest net external debt among the founding members of the euro area. External debt was the main component of the international investment position. We split external debt between public and private sectors due to the different conditions that exist when accessing external funding. Additionally, we use quarterly data and estimate how external debt determined variations in the channels of transmission through which external debt may affect economic growth. Only some channels were significantly affected by external debt: the private and public external debt increased public investment, and private external debt damaged private investment. Therefore, external debt was not allocated to positively and significantly increase economic growth. Additionally, financial integration in the euro area and financial stress in Europe affected some channels of transmission. It would be advisable to reduce external debt through a positive current account, to assign external debt to tradable sectors that will obtain a higher return on investments, and to shift external funding from debt instruments to equity ones.
\end{abstract}

Keywords External debt · Economic growth · Public sector · Private sector · Portugal

JEL Classification C22 $\cdot$ E44 $\cdot$ F34

The opinions expressed are those of the author and not necessarily those of his employer.

I thank António Afonso, Luís Catão and two anonymous referees for the useful comments.

Jorge Silva

jorge-faria.silva@ar.parlamento.pt

1 Portuguese Parliament, Parliamentary Budget Office, Lisbon, Portugal 


\section{Introduction}

The relationship between economic growth and debt is an attractive subject in the macroeconomics field. High levels of public debt, private debt and external debt may impact economic growth and assign future resources. Previous literature on external debt focused on emerging economies individually or sets of countries. The innovation of our study is the simultaneous focus on three features: the split of external debt between public and private sectors, a highly indebted country and an advanced economy. ${ }^{1}$ Portugal had the highest net external debt-to-GDP ratio among the founding members of the euro area. In this study, we concentrate on the case of Portugal for the 1999-2019 period and highlight the relationship between the stock of external debt and economic growth. The euro currency was introduced in 1999 and consequently the monetary policy became an external variable.

Gros (2011) considered that external debt was the key factor during the European crisis in 2010-2011 and the focus on total public debt was misleading. Portugal was an example of how external debt is more important than public debt. Belgium and Portugal had similar fiscal positions and public debt-to-GDP in 2010, but financial markets were worried about Portugal. While Belgium was a net creditor, Portugal had a high external debt-to-GDP ratio. Therefore, the contribution of this study is to assess how external debt was (not) allocated to the channels of transmission through which external debt may affect economic growth.

Portugal has country-specific features that emerged after the introduction of the euro: low economic growth, high external debt-to-GDP, and the economic and financial adjustment programme (EFAP). ${ }^{2}$ While other studies have focused on public debt, we focus on external debt because this is a proxy for the funding of the economy as a whole (Gros 2011). Additionally, we split the external debt of the private and public sectors due to the different conditions that exist when accessing external funding. In this study, we use quarterly data and estimate the effects of leveraging and orderly deleveraging on the channels through which external debt may affect economic growth.

Therefore, we identify the amount of public debt held by non-residents. While public debt held by residents may not be very detrimental for the economic growth rate, government debt held by non-residents may have negative consequences on the external accounts and on economic growth. ${ }^{3}$ Furthermore, the external debt of the private sector could have an impact on private gross added value and would necessarily assign future resources generated by the private sector to the payment of interests to the rest of the world. The net external debt is the largest subset of the international investment position (IIP).

\footnotetext{
${ }^{1}$ This study follows the countries' classification of the International Monetary Fund's reports.

2 The EFAP was the agreement between Portugal and three international institutions (the International Monetary Fund, European Central Bank and European Commission), implemented during the 20112014 period. This program aimed at supplying external funding to the general government and designing structural reforms in the Portuguese economy.

${ }^{3}$ Notwithstanding, public debt exclusively held by residents would result in risk for holders due to lack of diversification.
} 
A sustainable trajectory of the net external debt requires that the resident institutional sectors have the capacity to generate future resources and pay interests to non-residents over the medium and long run. Additionally, a sustainable trajectory cannot jeopardize the rollover of external debt, reduce the potential output growth and crowd out the other components of the IIP.

During the 1999-2019 period, the low economic growth rate did not generate abundant resources to simultaneously pay interests and increase investment. The increasing share of portfolio investment and debt instruments resulted in vulnerability to financial markets (Faria et al. 2007). The increasing external debt made rollover difficult, and the sudden stop in 2010 led to the EFAP. This country-specific analysis may be useful for small open economies in a monetary union.

This paper is organized as follows: Sect. 2 presents the literature review, Sect. 3 addresses the theoretical framework, Sect. 4 details the data, Sect. 5 presents the methodology, Sect. 6 discusses the results, Sect. 7 presents the robustness analysis, and Sect. 8 concludes.

\section{Literature review}

The previous literature related with external debt and economic growth focuses on panel data and case studies on emerging economies. It is useful to identify which are the channels of transmission through which external debt affected economic growth. Therefore, the contribution of our study is to close the gap between the previous literature and the focus on a high indebted advanced economy. Panel data studies focus on many countries in general, but not specifically on a single country. This manuscript focuses on Portugal and is an in-depth assessment of the country.

During the period of the European sovereign crisis, Gros (2011) focused on the external debt as the key to the financial mess in European countries. The author considered Portugal and Belgium as the examples of how financial markets were worried on external debt. These two countries had similar poor fiscal positions and debt in 2010, but Portugal had a high net external debt while Belgium was a high net creditor. Therefore, the total focus on the public debt ratio was misleading.

Tosktas et al. (2019) developed a causality analysis between two variables: net foreign debt stock and economic growth. The authors assessed the period 2003Q1-2017Q1 in Turkey. They concluded there was a causality relationship between the two variables, including both negative and positive shocks.

Afonso and Jalles (2013) studied the links between growth, productivity and government debt. The authors used a panel estimation of 155 countries for the 1970-2008 period. They concluded that fiscal consolidation promoted growth in a non-Keynesian fashion. There was a negative impact of the government debt ratio on growth for the full sample, and with higher household and government debt there was lower output growth. Higher debt ratios had a positive impact on total factor productivity (TFP), but were detrimental to public and private investment. In the case of the OECD countries, debt maturity increased economic growth, while financial crises were detrimental to growth. The authors found endogenous debt ratio thresholds of $59 \%$ for the full country sample and 58\% for the euro area countries. 
In addition, an increase of $10 \%$ in the debt ratio had a negative (positive) impact on growth in the case of countries with a debt ratio above (below) $90 \%$ (30\%).

Pattillo et al. (2011) assessed the non-linear impact of external debt and of debt reduction on economic growth for 93 developing countries during the 1969-1998 period. The methodology used was fixed effects as well as generalized method of moments to control for potential endogeneity. The dataset included nominal debt and net present value of external debt. The results suggest that the impact of debt became detrimental at about $160-170 \%$ of exports or $35-40 \%$ of GDP. Doubling debt could have slowed per capita economic growth rate by about 1/3p.p. to 0.5p.p.. In addition, investment was not the main channel through which external indebtedness reduced the economic growth rate. In fact, the quality of investment and the TFP growth were the main channels.

Schclarek (2004) studied the relationship between debt and economic growth for 59 developing countries and 24 industrial countries for the 1970-2002 period. The author considered public and private debt, external debt as well as four different dependent variables: GDP per capita growth rate, the TFP growth rate, the capital accumulation growth rate, and the private savings rate. In the case of developing countries, lower external debt levels were associated with higher economic growth rates. This negative relationship was explained by public external debt. The main channel was the capital accumulation growth, while the relationship between TFP growth and external debt is limited. Private savings rates presented mixed results. There was no evidence for an inverted-U shaped relationship between external debt and economic growth. Regarding industrial countries, there was no significant relationship.

Reinhart and Rogoff (2010) focused on the links between public debt, economic growth and inflation in both developed and emerging countries. The study established some debt-to-GDP thresholds. Unexpectedly, the relationship between public debt and economic growth was found to be similar among emerging and advanced economies. Furthermore, in emerging markets, there was evidence of a more relevant threshold for total gross external debt, when compared with total public debt. The main conclusion of Reinhart and Rogoff (2010) was that both advanced countries and emerging markets with a high debt-to-GDP ratio were associated with remarkably lower economic growth.

Checherita-Westphal and Rother (2012) studied the impact of government debt on the GDP per capita growth rate in twelve euro area countries for the 1970-2008 period. The channels through which government debt had a non-linear impact on the economic growth rate were private saving, public investment and TFP. In addition, the authors consider the stock of private debt as an important variable when investigating the relationship between public debt and economic growth. The authors concluded that when debt levels were above the debt turning point between 90 and $100 \%$ of GDP, there were lower long-term growth rates.

Regarding the Portuguese economy, Reis (2013) studied the low economic growth rate between 2000 and 2012. During this period, Portugal grew less than the USA during the Great Depression and less than Japan during its Lost Decade. Reis (2013) presented a new hypothesis to clarify this evidence, i.e. the misallocation of abundant capital flows from abroad. If financial integration exceeds financial 
deepening, productivity will fall and generate a slump. Furthermore, relatively unproductive firms in the non-tradable sector expanded at the expense of more productive tradable firms.

During the slump, there were large capital inflows from abroad, which allowed a steady growth rate of consumption. An increase of capital inflows due to a fall in the interest rate at which Portugal could borrow from abroad allowed a consumption boom as well as large capital inflows to finance it, which decreased net foreign assets. Portugal had low financial deepening, which caused largely misallocated capital inflows, an expansion of the unproductive non-tradable sector, and a fall in productivity.

\section{Theoretical framework}

Here, we discuss how external debt may affect the channels of transmission to economic growth. Despite some channels having been mentioned in the previous literature (Afonso and Jalles 2013; Pattillo et al. 2011; Schclarek 2004), some of them may not be affected by external debt in the Portuguese case. The following paragraphs aim at providing theoretical explanation for the estimations in the Sect. 6.

\section{Private saving}

The stock of external debt and the level of interest rates determine the amount of future interest payments demanded of Portugal. Higher (net) external debt has a permanent impact on the primary income account due to higher interest payments (Schclarek 2004; Checherita-Westphal and Rother 2012). In addition, there is a decrease of the available income of families, which leads to less consumption and/ or saving. ${ }^{4}$ The amount of external debt of financial and non-financial corporations determines the future interest payments from these Portuguese institutional sectors to non-residents.

\section{Public investment}

External debt may fund public investment. However, a high stock of external debt of the public sector determines a high level of payments to foreign institutions and a reduction of the primary income account (Checherita-Westphal and Rother 2012; Pattillo et al. 2011). This amount of interest payments decreases the fiscal space of the government budget to finance projects. Considering the objective of fiscal consolidation, the government may cut primary expenditure allocated for public investment, including the creation and maintenance of public infrastructure. Therefore, higher debt interest payments may reduce the fiscal space in the government budget and reduce social transfers and public investment.

\section{Real GDP per person employed}

In the public sector, external debt may increase the public expenditure on salaries (higher number of civil servants) and the purchase of goods and services as well as public investment. If there is a low marginal propensity to import, the fiscal

\footnotetext{
4 The amount of external debt of households is residual. However, financial institutions may borrow from the international financial markets and lend to households for consumption.
} 
multiplier is larger. This positive impact requires a large share of public investment, consumption by civil servants and the purchase of nationally produced goods and services. In this manner, public external debt may allow an increase in GDP. In the private sector, external debt may finance investment and increase the stock of capital (Schclarek 2004; Pattillo et al. 2011). If the new investment is based on expensive high technology, there needs to be an improvement in productivity and in the rate of return on investment to pay interests on the external private debt. However, this positive impact may be weaker if a large share of the investment is from imports.

\section{Gross value added per person employed in the private sector}

The amount of external debt may be allocated to finance private investment and increase the ratio of the stock of capital per worker (Schclarek 2004; Pattillo et al. 2011). Therefore, if the private sector were able to achieve a rate of return on investment higher than the interest rate of the external debt, a positive impact of private external debt on productivity and economic growth would be possible.

\section{Total factor productivity in the private sector}

Many factors may affect TFP, although it is not easy to identify them. The degrees of capacity utilization of labor and capital as well as the level of efficiency have been presented as the main factors. However, external debt may also be a factor with an impact on capacity utilization and efficiency (Pattillo et al. 2011; Schclarek 2004; Checherita-Westphal and Rother 2012). In fact, external debt may allow higher levels of investment and stock of capital to achieve an optimum level and economies of scale. Therefore, these companies can sell products and services in external markets, which means an improvement in competitiveness.

\section{Investment in the private sector}

The external amount of debt of the private sector may have a positive or negative impact on private investment (Schclarek 2004; Pattillo et al. 2011). On one hand, the amount of external debt may allow financing higher investments and increase the stock of capital, as well as economies of scale and improvement of knowledge. Furthermore, external debt may allow access to new business through mergers and acquisitions. On the other hand, a high level of external debt and a high amount of interests, the external debt reduces the ability of non-financial corporations to invest and increase the stock of capital. In addition, financial institutions reduce lending due to high leveraging, which has an impact on the investment of non-financial corporations.

\section{Primary income account}

The high net external debt (negative IIP) determines a structural negative primary account in the following periods. Therefore, when there is a structural decrease in the primary income account, it is more difficult to achieve equilibrium of external accounts, since the balance of payments naturally includes the primary income account. When there is a reduction in the primary income account, the trade balance needs to increase (and/or balance of capital, secondary income account) to attain the equilibrium of the balance of payments and offset the reduction of the primary income account (Gros 2011). Therefore, in the case of a lack of improvement in exports, a decrease in imports will be required. However, imports include public and private consumption as well as investment, but a reduction in investment is detrimental to potential output growth. 


\section{Data}

The main sources are Statistics Portugal (INE) and Banco de Portugal (BdP). The timeframe of this study is the 1999-2019 period. The quarterly data from national accounts were released by $I N E$ and financial data from $B d P$.

We consider the public sector, private sector and total economy. The institutional sectors underlying the European accounts system are general government, households, non-financial corporations, financial corporations and the rest of the world. The public sector is the general government, while the private sector comprises the remaining institutional sectors. ${ }^{5}$

The external variables are economic indicators that are benchmarks of the euro area (Table 1). The Portuguese economy is affected by external variables, but it does not impact them. In fact, external variables are exogenous regressors.

We include external variables related to financial markets released by the European Central Bank (ECB). The composite index of systemic stress (CISS) is a proxy for financial volatility in Europe. Financial integration in the euro area is a proxy for the cross funding between countries. This study considers the share of monetary financial institutions cross-border holdings of debt securities issued by euro area (corporate and sovereign bonds). In addition, we include the euro area economic growth and the German sovereign yield.

The domestic variables are indicators released by the Portuguese statistics authorities: INE and $B d P$. The Portuguese human capital was download from the Federal Reserve Bank of St. Louis.

\section{Methodology}

We use a model that considers as the dependent variables the channels through which external debt may impact economic growth. Equation (1) presents the model to assess the effects of external debt ratios, as well as domestic and external variables on the dependent variable:

$$
\Delta^{4} Y_{t}^{i}=\beta_{0}^{i}+\beta_{1}^{i} \Delta^{4} E x t d e b t_{t-j}^{p r i v}+\beta_{2}^{i} \Delta^{4} E x t d e b t_{t-j}^{p u b}+\beta_{3}^{i} \Delta^{4} X_{t}^{i, t o t a l}+u_{t}^{i} .
$$

The dependent variable $\Delta^{4} Y_{t}^{i}$ is the channel $i$ through which external debt may impact economic growth; $\Delta^{4} E^{t} x t e b t_{t-j}^{p u b}$ is the year-on-year change in the ratio between gross external debt of the public sector and GDP in quarter $t-j$; $\Delta^{4}$ Extdebt $_{t-j}^{\text {priv }}$ is the year-on-year change in the ratio between gross external debt of the private sector and GDP in quarter $t-j$; and $\Delta^{4} X_{t}^{i, t o t a l}$ is the set of domestic and external control variables. ${ }^{6}$

\footnotetext{
5 Other approaches would also be possible. For example, Reis (2016) considered the central bank and the government fiscal agents in the economic sense.

${ }^{6}$ Other studies consider different approaches. For example Tosktas et al. (2019) assessed the causality relationship between economic growth and foreign debt.
} 


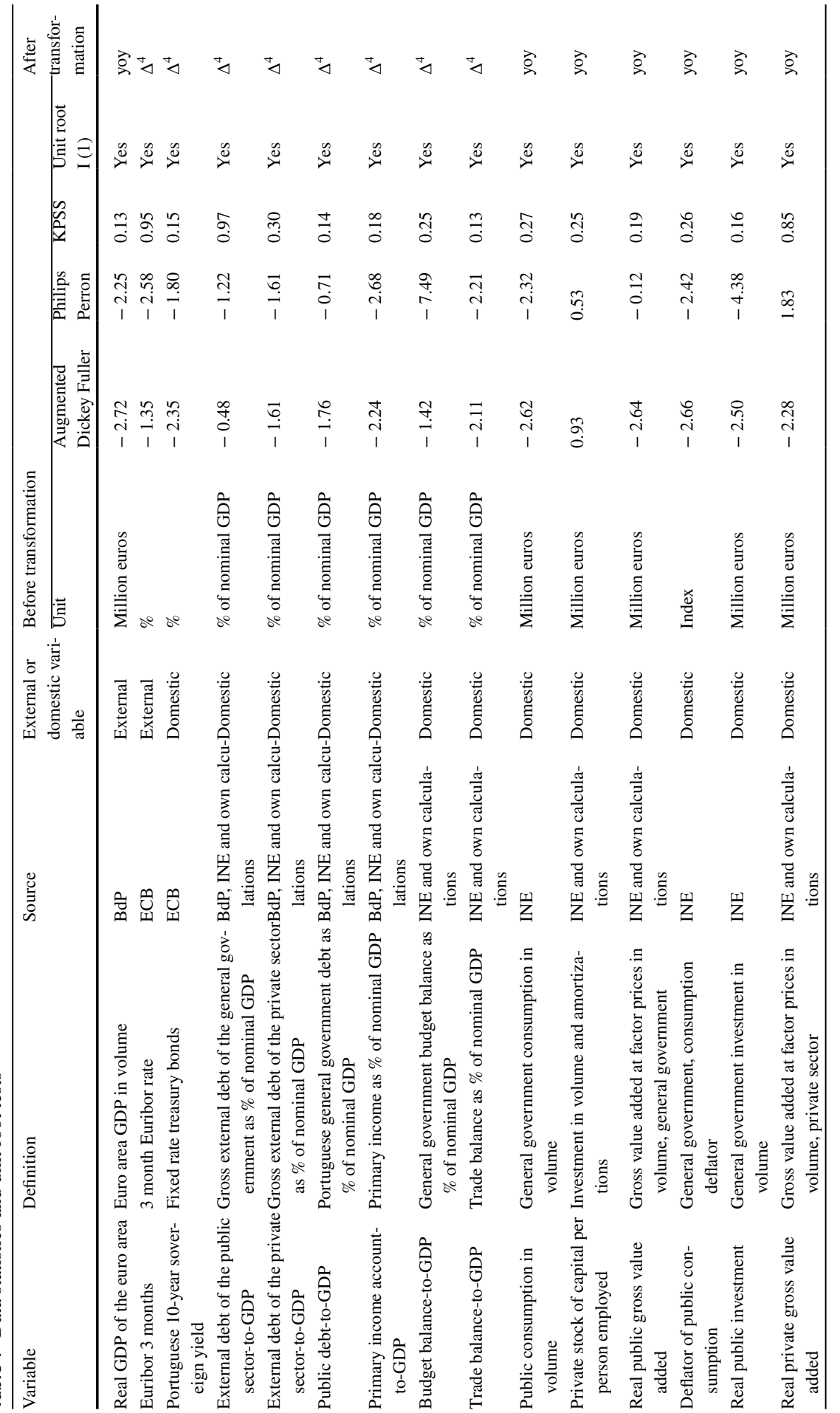




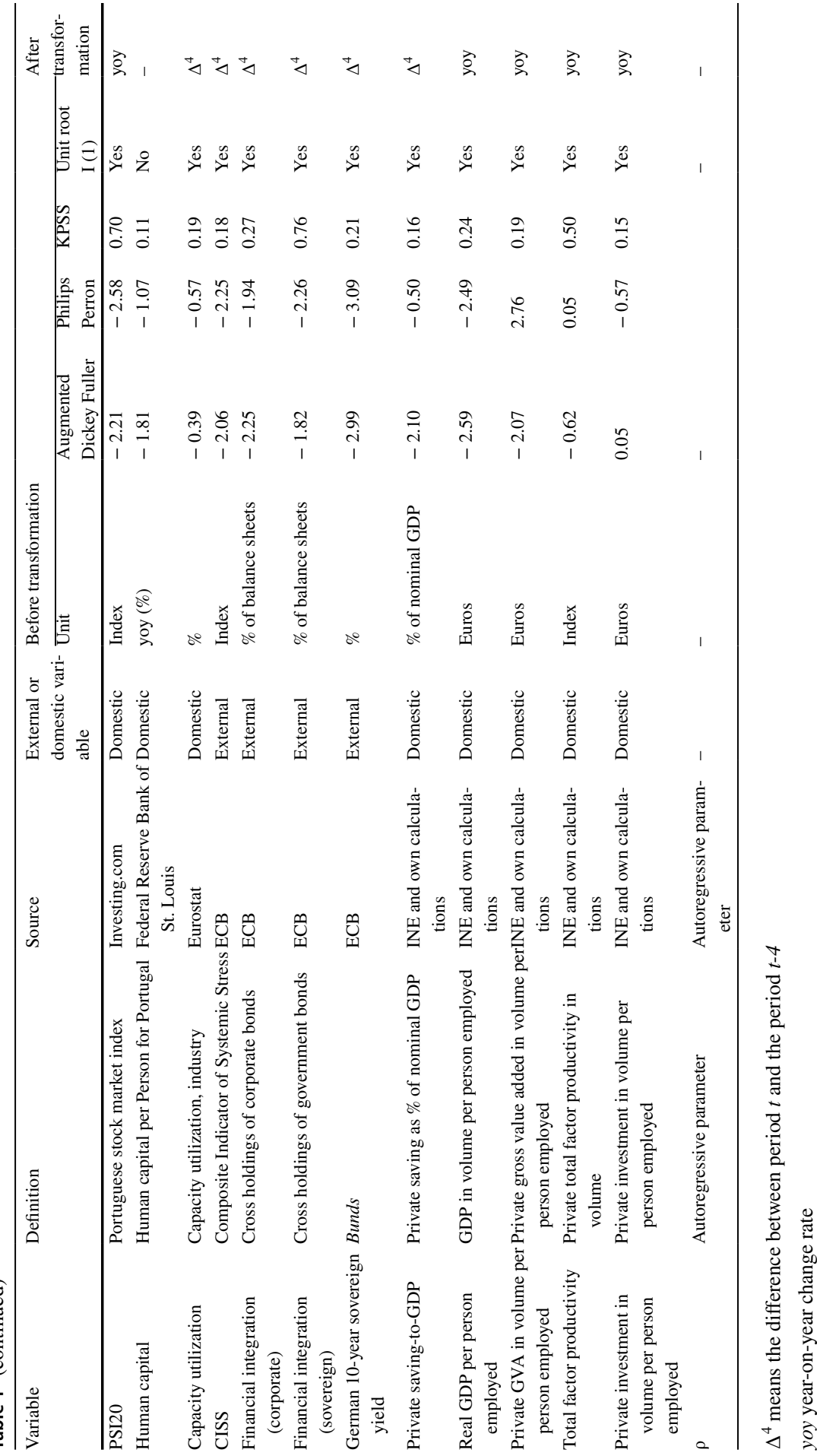


There is a strong relationship between public debt, private debt and external debt because the trajectory of each one impacts the other one. Checherita-Westphal and Rother (2012) presented a similar assumption.

After testing for stationarity, we concluded that the ratios of public and private external debt as percentage of GDP have unit root I (1). Therefore, we transform them to ensure stationarity I (0). Additionally, we apply transformations to other variables with unit root (Table 1).

This study focuses on gross external debt because it is a proxy for total funding. Therefore, it may include the funding by means of which the Portuguese institutional sectors purchase foreign assets. In the case of the public sector, gross external debt and net external debt are very similar.

Reinhart and Rogoff (2010) studied the impact of external debt on economic growth only in the case of emerging countries due to the scarcity of data for advanced economies. Here, we focus on the effect of external debt on a small open advanced economy, which has the highest external debt-to-GDP among the founding countries of the euro area. Portugal is highly dependent on external funding, as are many emerging countries.

\section{Results}

During the 1999-2019 period, the gross external debt-to-GDP ratio increased more than the net external debt-to-GDP ratio (Fig. 1). The increase of Portuguese assets around the rest of the world was weaker than the growth in Portuguese liabilities.

We decompose the Portuguese external debt into public and private sectors. There was an increase in leveraging of the private and public sectors until the financial crisis of 2009. In the aftermath of the 2009 financial crisis, the private external debt level shrunk sharply, while public external debt increased rapidly.

Additionally, there was a negative correlation between the net investment position and net external debt for the public and private sectors, because debt instruments were the largest share in liabilities. ${ }^{7}$

Regarding the private sector, there was an increase of both external liabilities and external assets (Fig. 2) before the financial crisis. Afterwards, there was a deleveraging during the EFAP and a stabilization after 2015. The net external debt of the private sector was low for many years over the 1999-2019 period. When we assess external liabilities and external assets, it is important to stress that there are different ratings/creditworthiness between debt liabilities and debt assets, as well as different interest rates levels. ${ }^{8}$ Therefore, in this study we focus on external liabilities (debt).

\footnotetext{
7 This study and the literature review focus on external debt, which is a subset of the IIP. However, there are studies that focused on other components of the external funding. For example, Cieślik (2020) focused on direct investment, which includes subsets of equity and external debt.

${ }^{8}$ It is important to stress that Fig. 2 presents external debt at market value, while reimbursement will be at nominal value.
} 
There was a similarity between gross public external debt and net gross external debt because the amount of public sector assets in the rest of the world is not sizeable. There was evidence of leveraging in the public sector during the 1999-2014 period. After 2015, general government debt-to-GDP reduced.

Regarding the trajectory of public debt, we decompose it between debt held by non-residents and debt held by residents (Fig. 3). The share of public debt held by non-residents in the total public debt is the gross public external debt. Throughout the 2000-2003 period, the public debt ratio was under the $60 \%$ threshold stipulated in the Stability and Growth Pact, while the public external debt was lower than the public debt held by residents. In the period 2004-2010, the public debt ratio rose above the threshold of $60 \%$ due to public external debt. On the other hand, during the European sovereign debt crisis (2010-2011), the weight of public external debt decreased due to the increase of debt held by residents and increases of debt from the central bank. During the EFAP, there were loans from international institutions and reimbursements of public debt at maturity. After 2015, there was a reduction of external public debt, partially offset by the increase in domestic public debt.

Concerning the split between public debt held by residents and public debt held by non-residents, Afonso and Silva (2017) compare the cases of Portugal and Ireland. The authors calculate the ratio between public debt held by non-residents and public debt held by residents and estimate their determinants during the 2000-2014 period. In Portugal, the results show that better fiscal positions, higher systematic stress in Europe and higher shares of monetary financial institutions' cross-border holdings of public debt increase the share of non-resident held debt, while rising sovereign yields decrease that ratio. For Ireland, the results are statistically weak.

During the EFAP, the increase in gross public external debt was greater than the reduction of gross private external debt. While the private sector presented orderly deleveraging in the 2010-2014 period, the public sector increased its external debt due to the funding received from international institutions to finance net borrowing.

In summary, the stylized facts were the following: the increase in external liabilities was greater than the increase in external assets, which meant higher net external debt; the increase of external debt led to the assignment of future resources demanded of Portugal; net external debt is higher in the public sector, while gross external debt is higher in the private sector; and the share of non-residents public debt became larger after the introduction of the euro.

The following subsections present the estimations by each channel of transmission. There is no multicollinearity between regressors. The following estimations include independent variables that are both external variables (euro area economic indicators) and domestic variables (Portuguese economic indicators). Therefore, some independent variables were not considered in the previous literature due to the different geographic scope. While Portugal is affected by euro area economic variables, emerging economies countries were affected by their specific features (Schclarek 2004; Pattillo et al. 2011). 


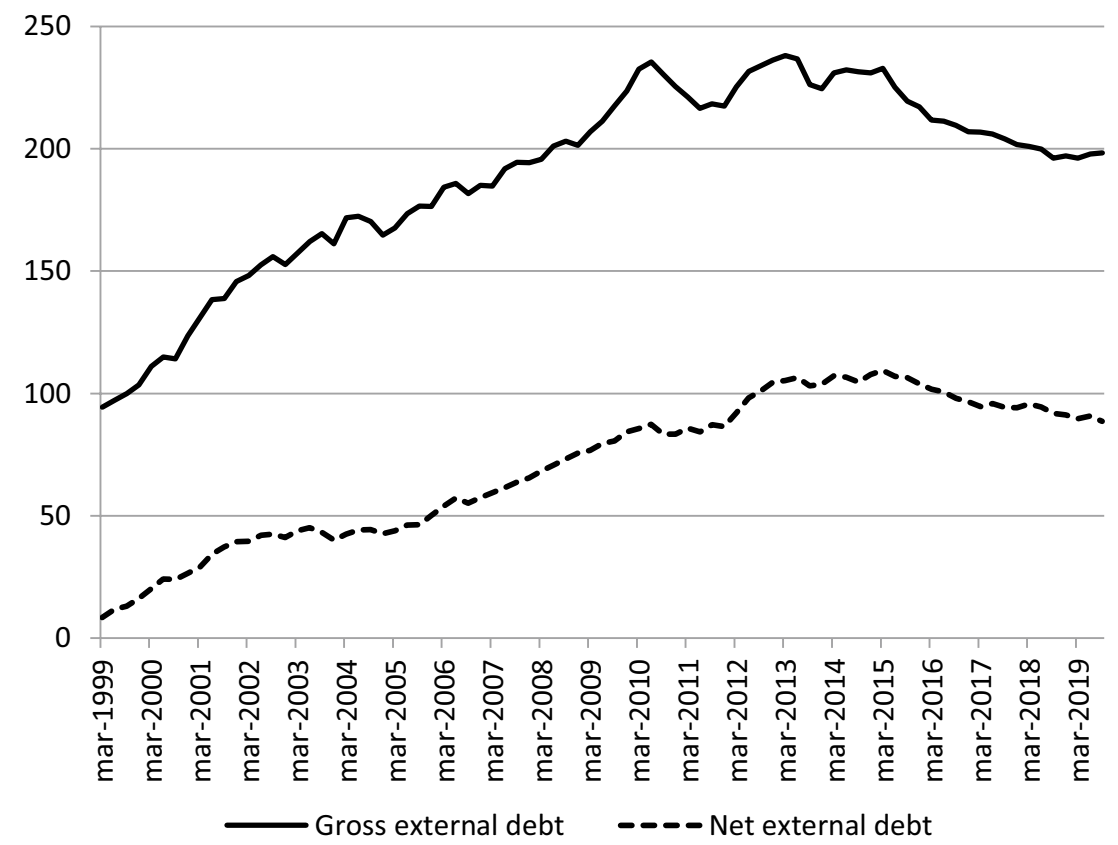

Fig. 1 Gross external debt and net external debt: total economy (percentage of GDP). Source: $B d P$ Banco de Portugal (2020), INE Statistics Portugal and own calculations (2020)

\subsection{Private saving, public investment and GDP}

\section{Private saving}

The variation of the private saving-to-GDP ratio was affected by the 3-month Euribor rate (Table 2). A positive variation of 100 basis points decreased the private saving as percentage of GDP by 0.92p.p. (regression 4). This result was explained by the private sector's higher interest payments than revenues. Unexpectedly, the primary income account has no statistical significance.

Financial stress in Europe was detrimental for private saving (regression 4) because financial volatility may be related to higher interest payments. Higher financial integration meant less private saving. During the periods of increasing cross funding between countries, it is easier to borrow external funding to finance consumption and investment. Private saving was not needed to finance domestic investment.

The variation in the external debt of the public sector has no statistical significance (regression 4). Variations in the gross private external debt ratio had an effect on private saving, but the coefficient is low. This result suggests that if the government increases external debt, and private institutional sector does not increase its saving and do not expect future increases in taxes, there is absence of Ricardian equivalence. 


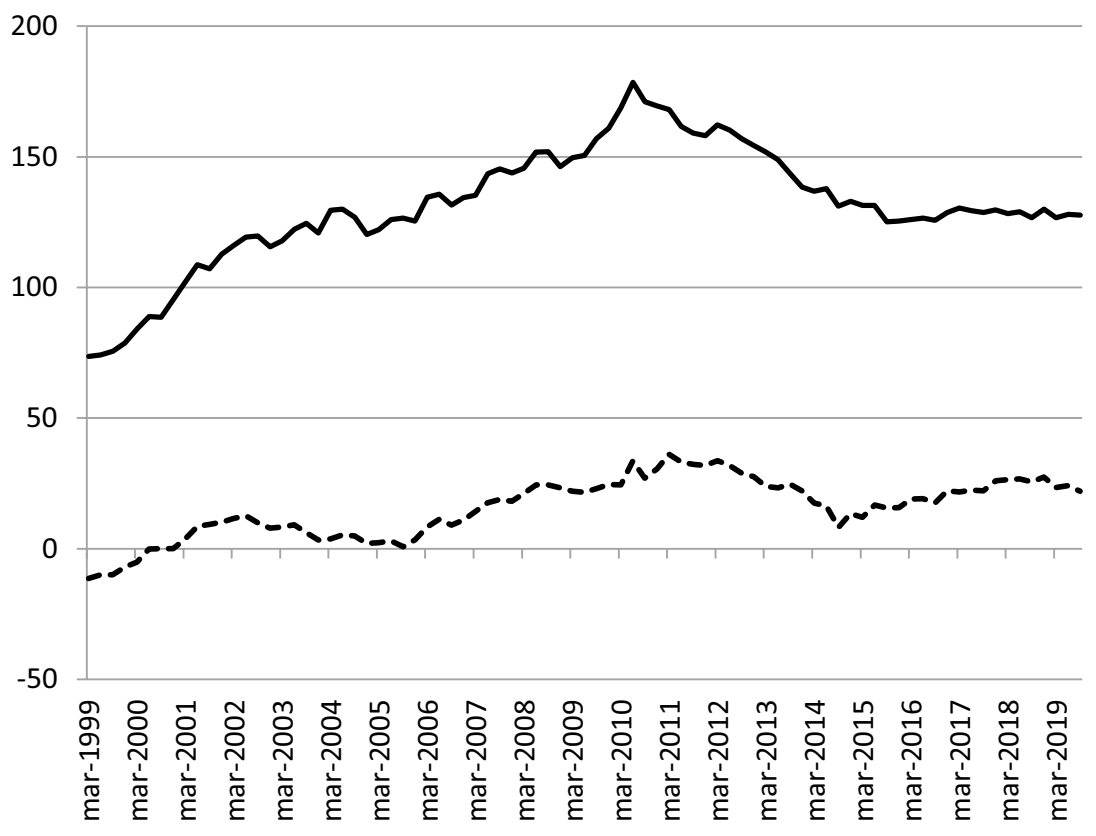

- - Net external debt: private sector — Gross external debt: private sector

Fig. 2 Gross external debt and net external debt: private sector (percentage of GDP). Source: $B d P$ Banco de Portugal (2020), INE Statistics Portugal and own calculations (2020)

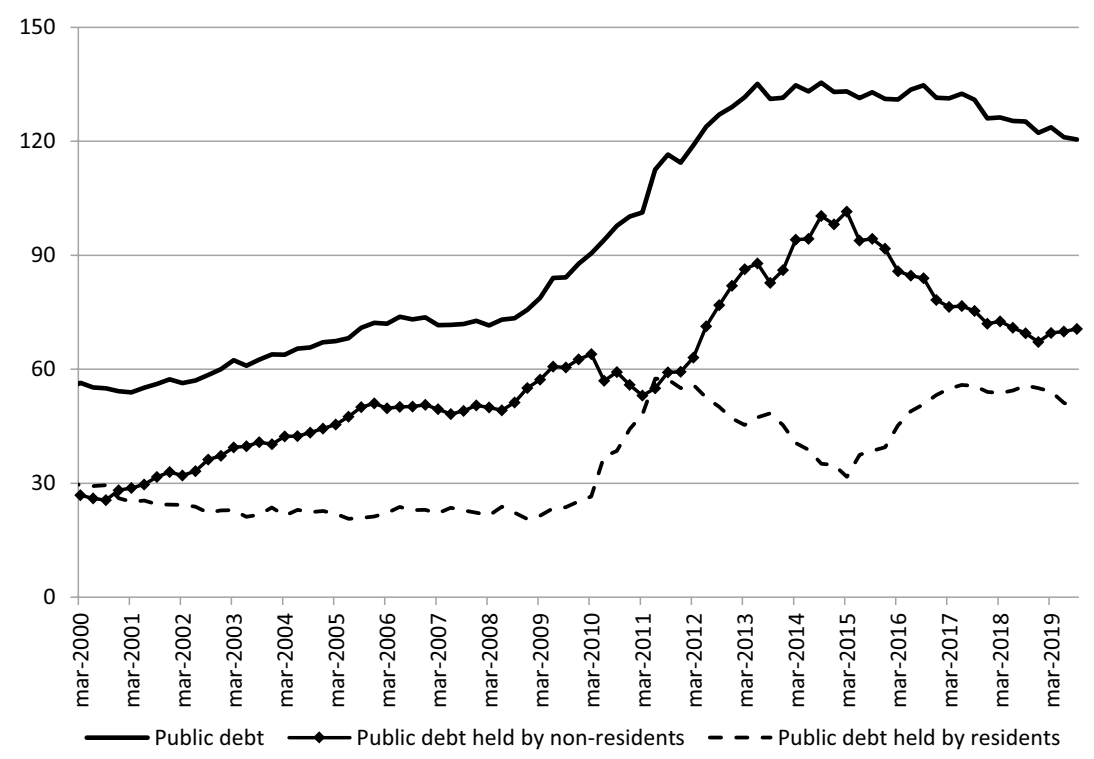

Fig. 3 Public debt: total, held by non-residents (external debt) and held by residents (percentage of GDP). Source: BdP Banco de Portugal (2020), INE Statistics Portugal and own calculations (2020) 


\section{Public investment}

In regression 8 (Table 2), an increase of the lagged public debt-to-GDP ratio (1p.p.) had a negative effect on the growth rate of real public investment (2.41p.p.). This result suggests that the increase of public debt in previous quarters was offset by the reduction of public investment. In addition, a higher budget balance (lagged) positively affected public investment in volume. Therefore, public finances' performance affected the public investment in the following periods.

Financial integration in the euro area corporate bonds affected negatively the Portuguese public investment. This result may suggest that cross border funding may have been allocated to the private sector in other euro area countries.

There was evidence of a positive effect on public investment from both private and public external debt. This suggests that external debt may have provided the funds for public investment. The coefficient linked to private external debt was lower than the coefficient associated to public external debt. This result was expected, because public external debt provides the funding for current spending and public investment. However, private external debt may have been channelled to fund the private and public sectors.

\section{Real GDP per person employed}

There was difference between GDP per person employed and GDP per capita due to the variation of the employment-to-population ratio. This discrepancy is explained by changes in the unemployment rate and labor force participation rate. In this study, we focus on GDP per person employed because this variable is a better proxy for the evolution of productivity.

The growth rate of the euro area was determinant for the growth of GDP per person employed in Portugal (Table 2). However, it is important to stress that the variation rate in GDP per person employed in Portugal (column 12) was around 0.29\%, when the economic growth rate in the euro area was $1 \%$. There was a negative effect due to lagged variations of the Euribor rate. It is a proxy for interest rates and its increases negatively affected the Portuguese economy due to the negative IIP and tighter monetary policy. Financial stress in Europe had no statistical significance.

Unexpectedly, human capital was not statistically significant, which may be associated with a low total factor productivity growth.

Financial integration in sovereign bonds seems to have been a negative effect on real GDP per person employed. It may suggest less available funding to the private sector and consequently less economic growth.

Furthermore, the variation in the private and public external debt had no effect on economic growth and productivity. This result suggests that the return on external debt was not sizable due to the high import content and the low return on investment. Tosktas et al. (2019) used time series during the 2003Q1-2017Q1 period in an emerging market economy, Turkey. The authors concluded that there was a positive relation between net foreign debt and economic growth. 


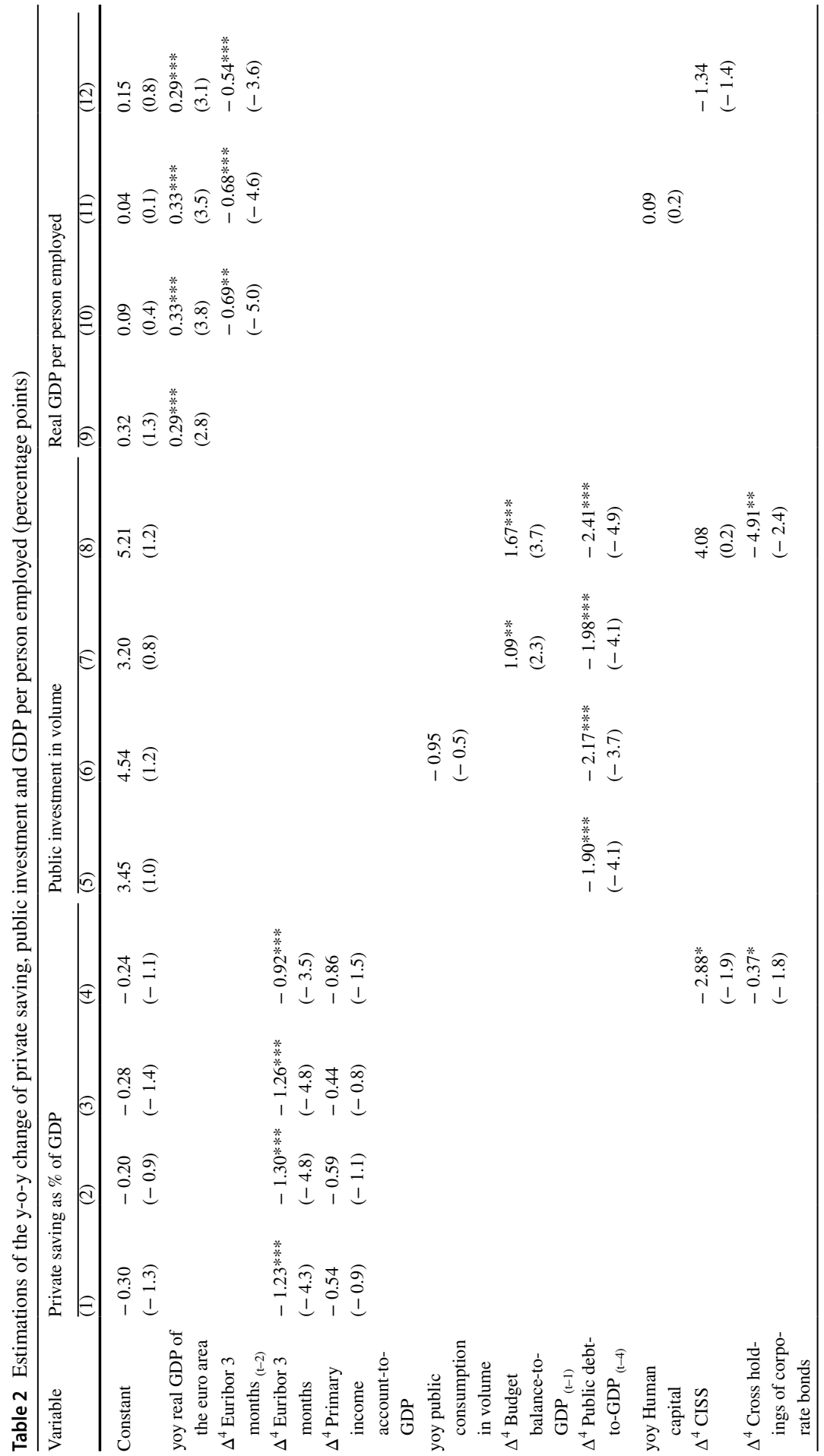




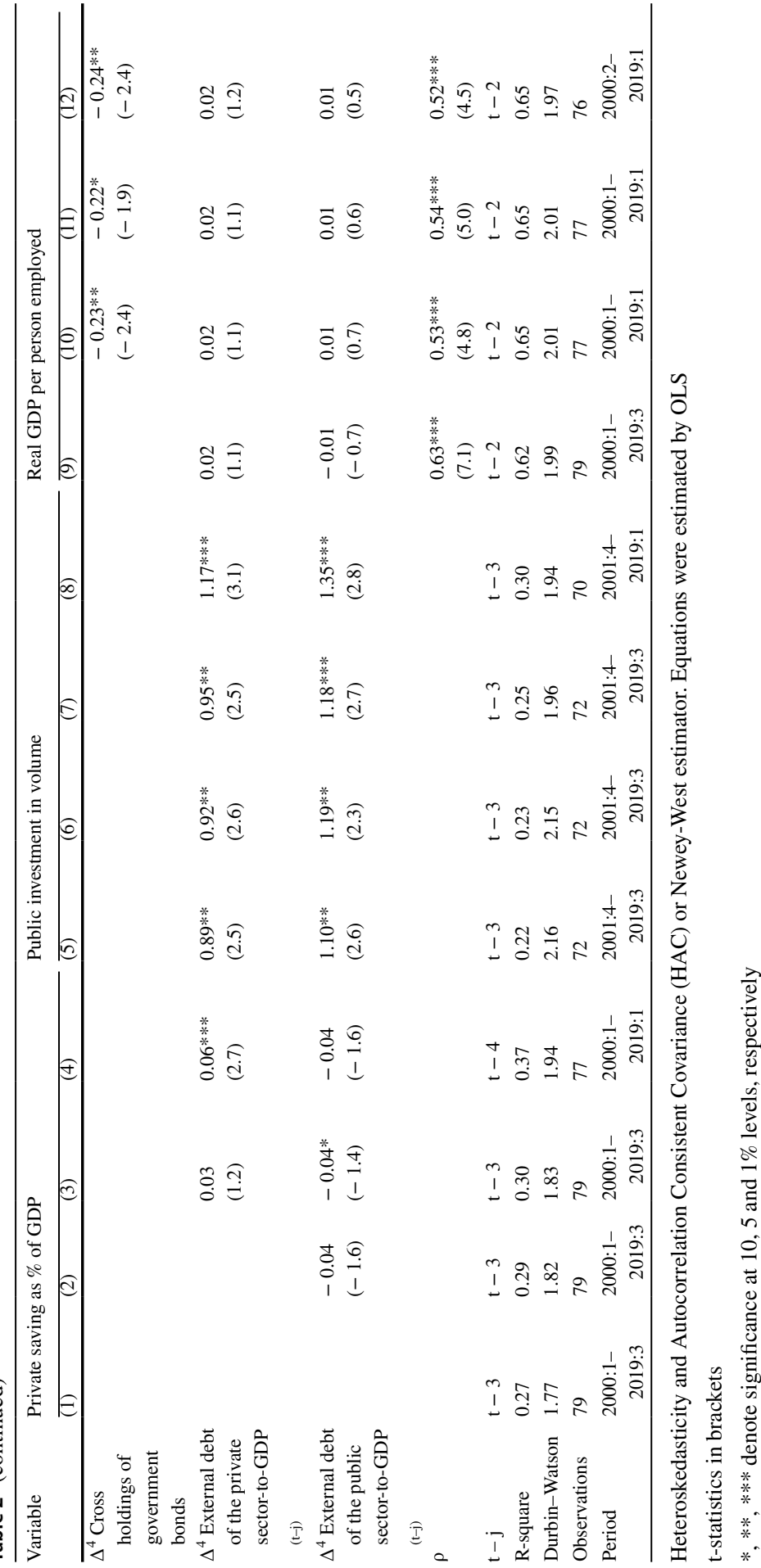




\subsection{Production function}

\section{Gross value added per person employed in the private sector}

We focus on the private production function per person employed because it is a proxy for the productivity in the private sector. Equation (2) is the production function of the private sector, where $Y_{t}$ is the GVA in volume of the private sector, $A_{t}$ is the TFP of the private sector, $K_{t}$ is the capital stock of the private sector and $L_{t}$ is the private employment. There will be only constant returns to scale if $1-\alpha-\beta=0$, where $\alpha$ is the elasticity of the real GVA to the variation of the stock of capital and $\beta$ is the elasticity of real GVA to the variation of employment.

$$
Y_{t}=A_{t} K_{t}^{\alpha} L_{t}^{\beta}
$$

The GVA per person employed is obtained by the ratio between $Y_{t}$ and $L_{t}$. In Eq. (3), $y_{t}$ means the GVA per person employed and $k_{t}^{\alpha}$ is the stock of capital per person employed.

$$
y_{t}=\frac{A_{t}}{L_{t}^{(1-\alpha-\beta)}} k_{t}^{\alpha}
$$

After some iterations, we find the growth rate of the GVA per person employed of the private sector, where $(1-\alpha-\beta) *\left(-\Delta \% L_{t}\right)$ is the probable effect in the absence of constant returns to scale. Therefore, Eq. (4) presents the decomposition of the growth rate of the GVA per person employed of the private sector when considering a general production function.

$$
\Delta \% y_{t}=\Delta \% A_{t}+(1-\alpha-\beta) *\left(-\Delta \% L_{t}\right)+\alpha * \Delta \% k_{t}+\varepsilon_{\mathrm{t}}
$$

There are many variables that can determine TFP, such as the external debt of the private and public sectors. Table 3 details the estimation results. Regression 1 took as an assumption a Cobb-Douglas production function, i.e. constant returns to scale and $\alpha+\beta=1$. The estimated coefficient was 0.20 , in which an increase of $1 \%$ in the stock of capital per person employed caused a positive variation of $0.20 \%$ of the ratio GVA per person employed. On the other hand, the estimations in regressions 2,3 and 4 considered the possibility of the absence of constant returns to scale and $\alpha+\beta \neq 1$. These estimations suggest decreasing returns to scale in the production function per person employed of the private sector. Therefore, increases in employment and stock of capital resulted in diminishing increases in the private GVA, which was a structural constraint.

Additionally, the constant term was not significantly significant. Therefore, it suggests that the increase in the TFP of the private sector may have been zero during the period of analysis. This result is unexpected and means that TFP did not positively affect economic growth.

Furthermore, variations in external debt had an effect on the production function per person employed of the private sector (regression 4), but the coefficients had a low magnitude. Therefore, external debt did not have a sizable positive effect on the private sector. This result suggests that the low growth rate of the private GVA was 
the result of a low return on private external debt. Consequently, external debt-toGDP rose.

\section{Total factor productivity in the private sector ${ }^{9}$}

There are some unexpected results (Table 3). Human capital and capacity utilization are not statistically significant. In addition, an increase of real GVA (1\%) of the public sector (regression 8) had a positive effect on the growth rate of TFP of the private sector (1.03p.p.). Furthermore, an increase of $1 \%$ in the deflator of public consumption had a negative effect on the rate of change of TFP (0.42p.p.). It is important to stress that these two variables are similar to the nominal GVA of the public sector. Consequently, the results suggest that the real (price) component of the public GVA impacted positively (negatively) the private TFP.

Furthermore, periods of increasing financial integration in corporate bonds affected positively the private TFP because it may have been easier to finance the aggregate demand. On the other side, financial stress had a negative impact on private TFP, which meant that financial instability was detrimental to productivity.

There is no evidence that gross external debt had an effect on the private TFP (regression 8). Therefore, increases in external debt did not raise the private sector productivity.

\section{Investment per person employed in the private sector}

We use the 2SLS estimator to solve endogeneity between real investment per person employed and GVA in volume per person employed (Table 3). The instrumental variable is the economic activity indicator. ${ }^{10}$ There is notably a strong correlation between this indicator and the private GVA in volume. The weak instrument diagnostic Cragg-Donald F-test shows that the economic activity indicator is an appropriate instrument.

Moreover, a positive variation of 1p.p. in real public investment decreased the $\mathrm{y}-\mathrm{o}-\mathrm{y}$ rate of change of real private investment per person employed by $0.14 \mathrm{p}$.p. (column 12), which meant a crowding effect between public and private investment. That effect may have been due to the lower amount of available funding to the private sector and higher interest rates. Unexpectedly, the Portuguese 10-year sovereign yield did not impact the growth of real private investment per person employed. The sovereign yield is a benchmark for the interest rates that the domestic private sector can borrow. In addition, an increase of the real GVA of the private sector (1p.p.) had a positive effect on the $y-\mathrm{o}-\mathrm{y}$ rate of change of growth of the private investment in volume per person employed (3.81p.p.).

Regarding the external funding, the private external debt (+1p.p.) impacted negatively the private investment in volume per person employed ratio ( -0.28 p.p.). Therefore, the increasing external debt did not result in large increases in private investment. Consequently, low investment suggests an absence of economies of

\footnotetext{
9 Although TFP was not statistically significant in regressions (1) and (2), we calculate it considering a Cobb-Douglas production function. It requires a constraint regarding the coefficients' elasticity to labor and capital: the weight of compensations' employees and the operating surplus.

10 The economic activity indicator is a coincident indicator. It is based on a set of variables and released from $B d P$.
} 


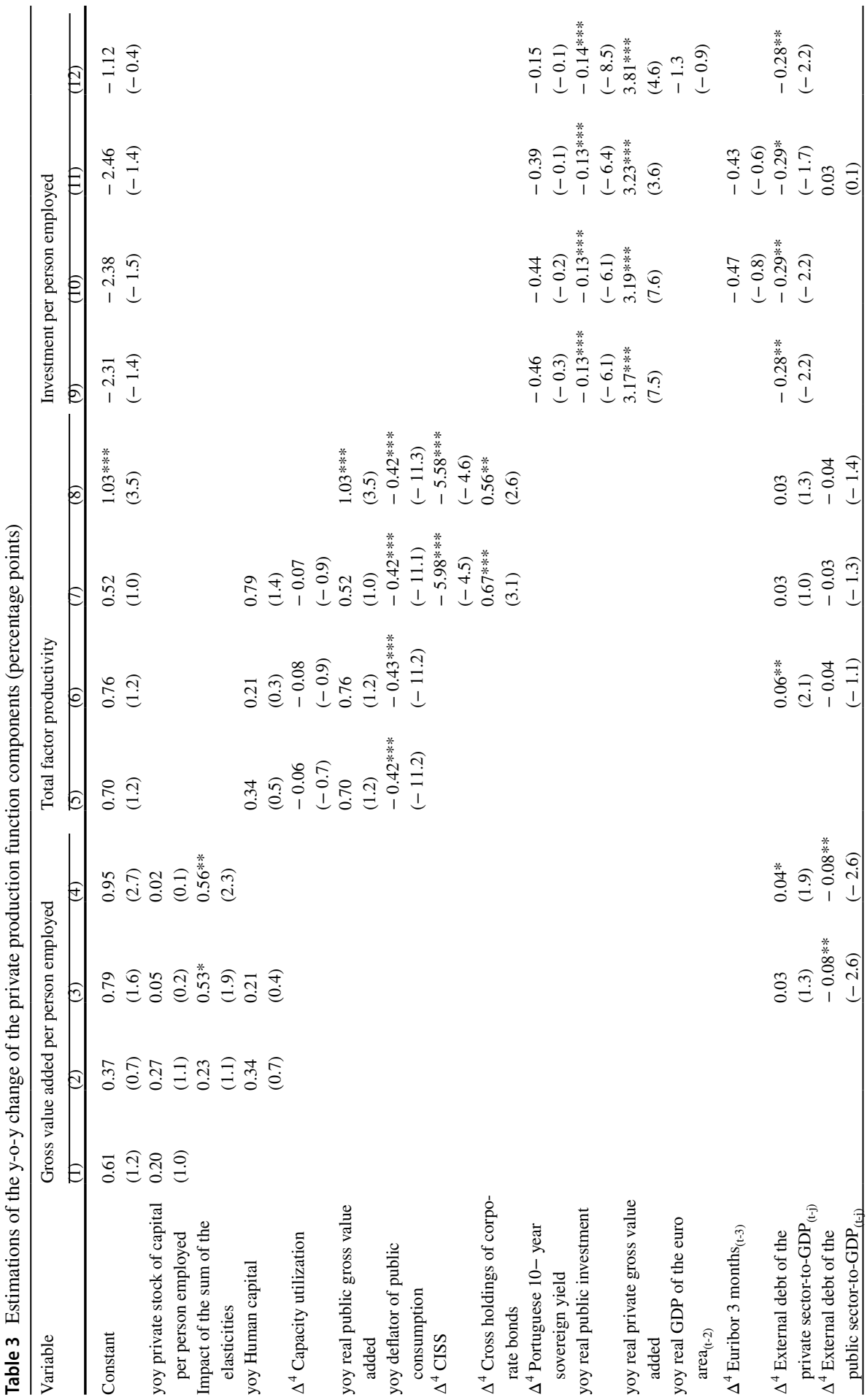




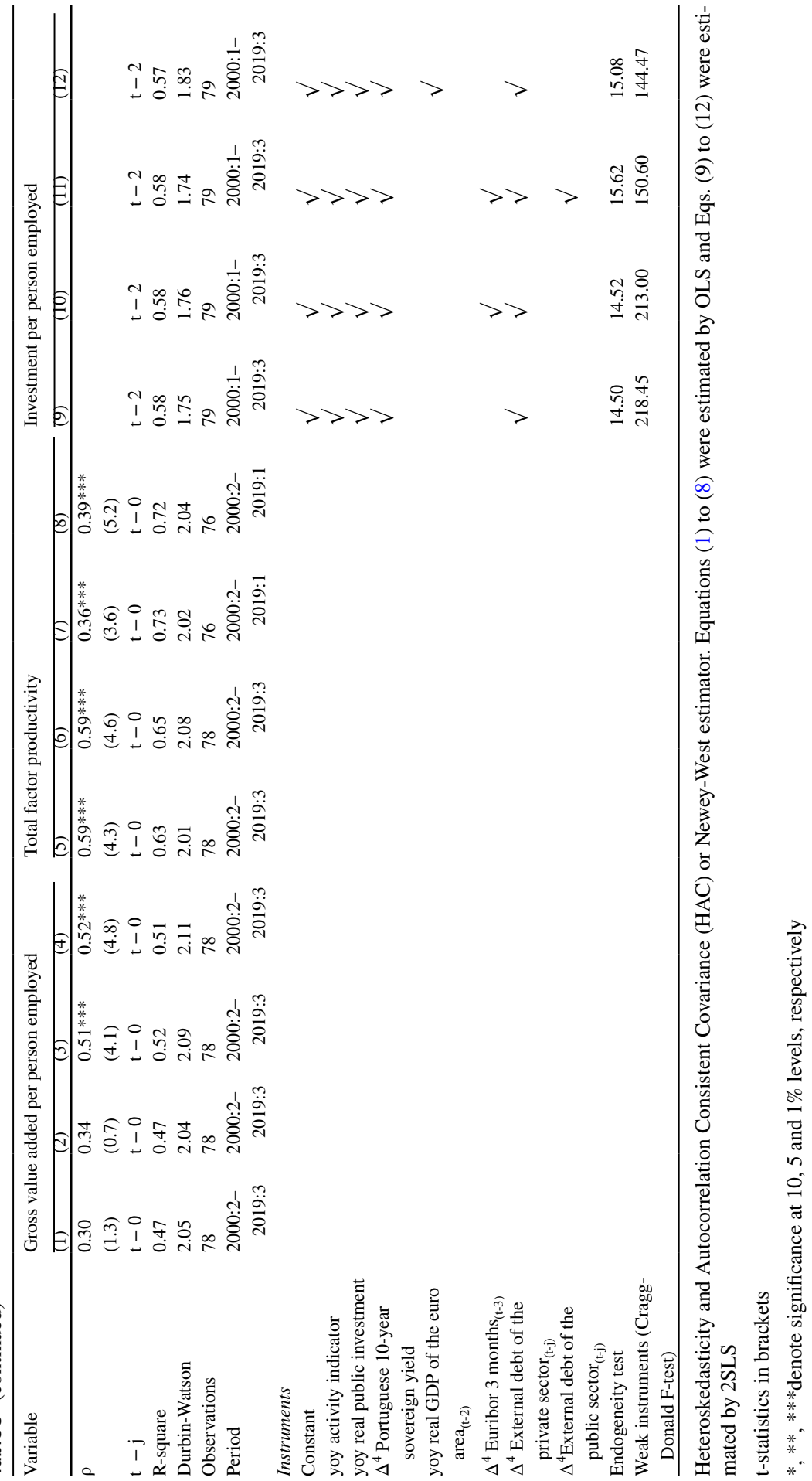


scale and a lack of improvement of knowledge. The public external debt is not statistically significant.

Unexpectedly, financial integration in the euro area and financial volatility in Europe did not impact the Portuguese private investment per person employed.

\subsection{External accounts}

\section{Primary income account}

We estimate the effect of external debt on the balance of payments, particularly on the primary income account. The negative IIP and the high stock of net external debt have a detrimental effect on the primary income account. It records financial flows stemming from transactions between residents and non-residents (Gros 2011). There are receipts and payments related to income from labor, direct investment, interests, portfolio investment and other investment. Consequently, the primary income account was negative due to three factors: the negative IIP, positive net external debt in the previous periods, and a gap between the interest rates paid and received (Fig. 6). These are structural effects of net external debt on the external accounts. Figure 4 shows the decomposition between the interests received (paid) from (to) the rest of the world.

The effect of trade balance on the primary income account was related to the 3-month Euribor rate (Table 4). For example (regression 1), when the 3-month Euribor was $3 \%$, the effect of a rise in the trade balance (1p.p.) on the primary income account was 0.12 p.p. of GDP $\left(0.04^{*}\left(3^{*} 1\right)\right)$. This result suggests that the higher the 3 -month Euribor, the higher the positive effect of a rise in the trade balance. In addition, higher financial integration in the euro area meant a decrease of the primary account.

During the periods of financial integration, it was easier to finance the current account external deficits. Therefore, it was possible to record external deficits. Regarding capital inflows, Reis (2013) used time series in Portugal during the 2000-2012 period and concluded that financial integration allowed misallocation of foreign capital flows between tradable and non-tradable sectors. Here, we conclude that financial integration had a negative effect on the primary income account due to capital inflows that determined high external debt-to-GDP ratios (and negative IIPto-GDP ratios).

Higher Portuguese sovereign yield was detrimental for the primary income account (regression 2). Variations in the Portuguese stock market index (PSI20) and German sovereign yield are not statistically significant.

Unexpectedly, the lagged rise of the private external debt positively affected the dependent variable, but the coefficient was low. Hence, despite a significant deterioration in the Portuguese net external debt, there had not been a corresponding fall in the primary income account (Fig. 4). Therefore, it is important to present a decomposition of the primary income account to understand how an increase of the net external debt of the Portuguese economy did not explain a deterioration of the primary income account. 
Regarding the liabilities, Fig. 5 shows that despite an increase of the amount of gross external debt, the amount of interests did not increase in the same proportion due to decreasing interest rates. In fact, the reduction in interest rates (effect price) was stronger than the increase in interest payments (effect quantity).

Additionally, considering the amount of interests and stock of external debt, it is possible to calculate a proxy of the interest rates of liabilities and assets. Except for 2007 and 2014, the interest rates underlying liabilities were higher than the interest rates underlying assets (Fig. 6). We conclude that not only the nominal amount, but also the interest rate level of the liabilities is higher when compared to assets. Throughout the period of analysis there was a significant reduction in the interest rates underlying liabilities and assets. This decrease was important to subdue the impact of increasing net external debt on the primary income account. The ECB launched the expanded asset purchase programs in January 2015, which determined the reduction of the interest rates in the euro area (the zero lower bound).

\section{Robustness analysis}

In this section, we discuss some relevant factors, notably the comparison between variation in external debt and economic growth.

We compare the path of GVA of the private sector and the real GDP of the total economy during the 1999-2019 period, as well as the external debt of the private and public sectors (Fig. 7). The growth of real GDP and GVA in volume of the private sector was around 10\% over ten years (1999Q4-2009Q4).

In the 1999Q4-2009Q4 period, real GDP increased around 10\%, while the external debt of the private sector increased by 83p.p. of GDP (net external debt increased 32p.p. of GDP) and external debt of the public sector increased 38p.p. of GDP. During the 1999-2009 period, the sum of the variation of real GDP (i.e. the sum of flows detailed in Eq. (5)) was $80.4 \%$ of realGDP ${ }_{1999}$. However, the stock of external debt increased around 224.5p.p (157.4p.p. and 67.1p.p. of the private and public sectors, respectively) as measured by nominal $G D P_{1999}$ (Eq. (6)):

$$
\begin{gathered}
\text { Sum of the variation of real GDP }=\int_{t=1999}^{2009}\left[\text { real } G D P_{t}^{\text {total }}-\text { real } G D P_{1999}^{\text {total }}\right], \\
\qquad \text { extdebt }_{1999-2009}^{\text {total }}=\left(\frac{\text { extdebt }_{2009}^{\text {total }}}{G D P_{1999}^{\text {nominal }}}-\frac{\text { extdebt }_{1999}^{\text {total }}}{G D P_{1999}^{\text {nominal }}}\right) .
\end{gathered}
$$

In the 2010-2014 period there was a deleveraging of the external debt of the private sector, while the public sector debt held by non-residents increased (public external debt). In addition, the total economy real GDP and the private GVA in volume decreased. There was a larger gap between real GDP of total economy and GVA in volume of the private sector. This larger gap was explained by a reduction 


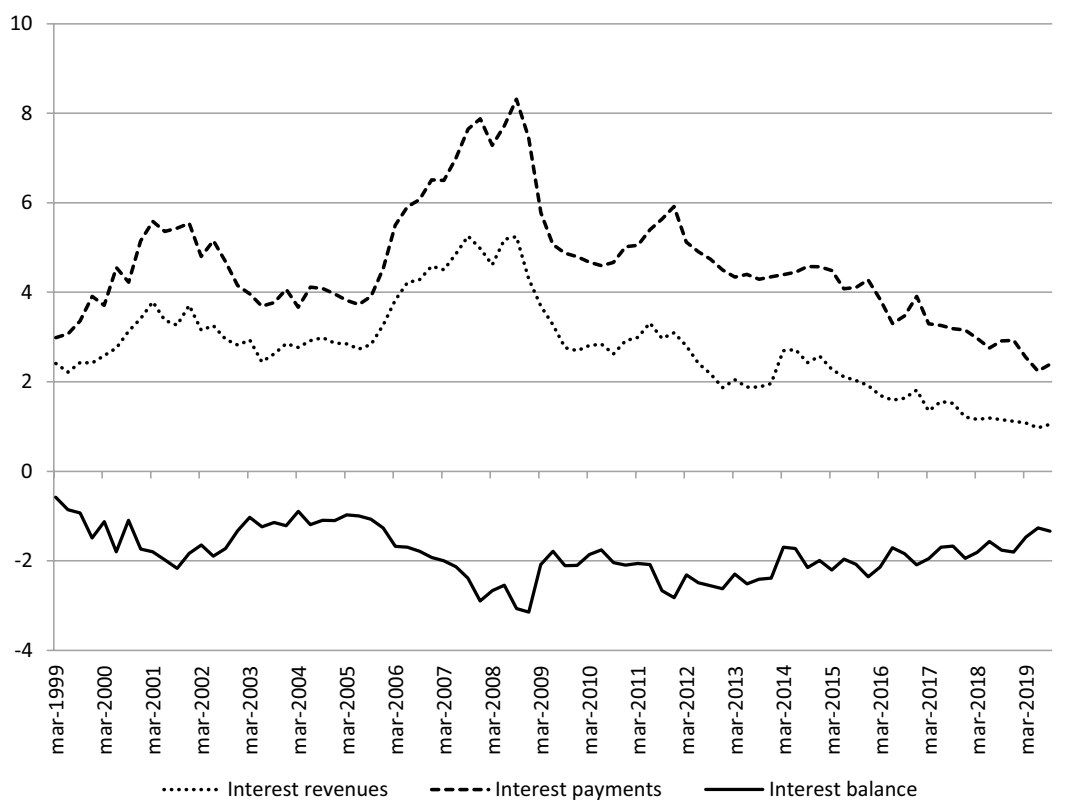

Fig. 4 Interests: revenues, payments and balance (percentage of GDP). Source: $B d P$ Banco de Portugal (2020), INE Statistics Portugal and own calculations (2020)

of real GVA of the public sector. After 2015 the public sector reduced the external debt.

Our findings agree with Reis (2013). The author refers that the increasing external debt made Portugal financially integrated in the euro area. The large flows of external debt allowed the expansion of the non-tradable sector. During the financial crisis in 2009 , Portugal was exposed to volatility in financial markets and affected by the sudden stop in 2010. In this study, our results suggest that the channels of transmission through which external debt could have impacted economic growth were not positively and significantly affected. As a consequence, external debt did not result in growth in the productive factors of the private sector.

\section{Conclusions}

We assessed the likely impact of the external debt of the private and public sectors on the Portuguese economic growth for the 1999-2019 period. We used quarterly data and estimated the effects of the external debt on the channels of transmission through which external debt may affect economic growth.

The increasing variation in the Portuguese external debt seems to have been unsustainable up to the European sovereign debt crisis. The rise of external debt was greater than the increase in productivity, investment and private GVA. 


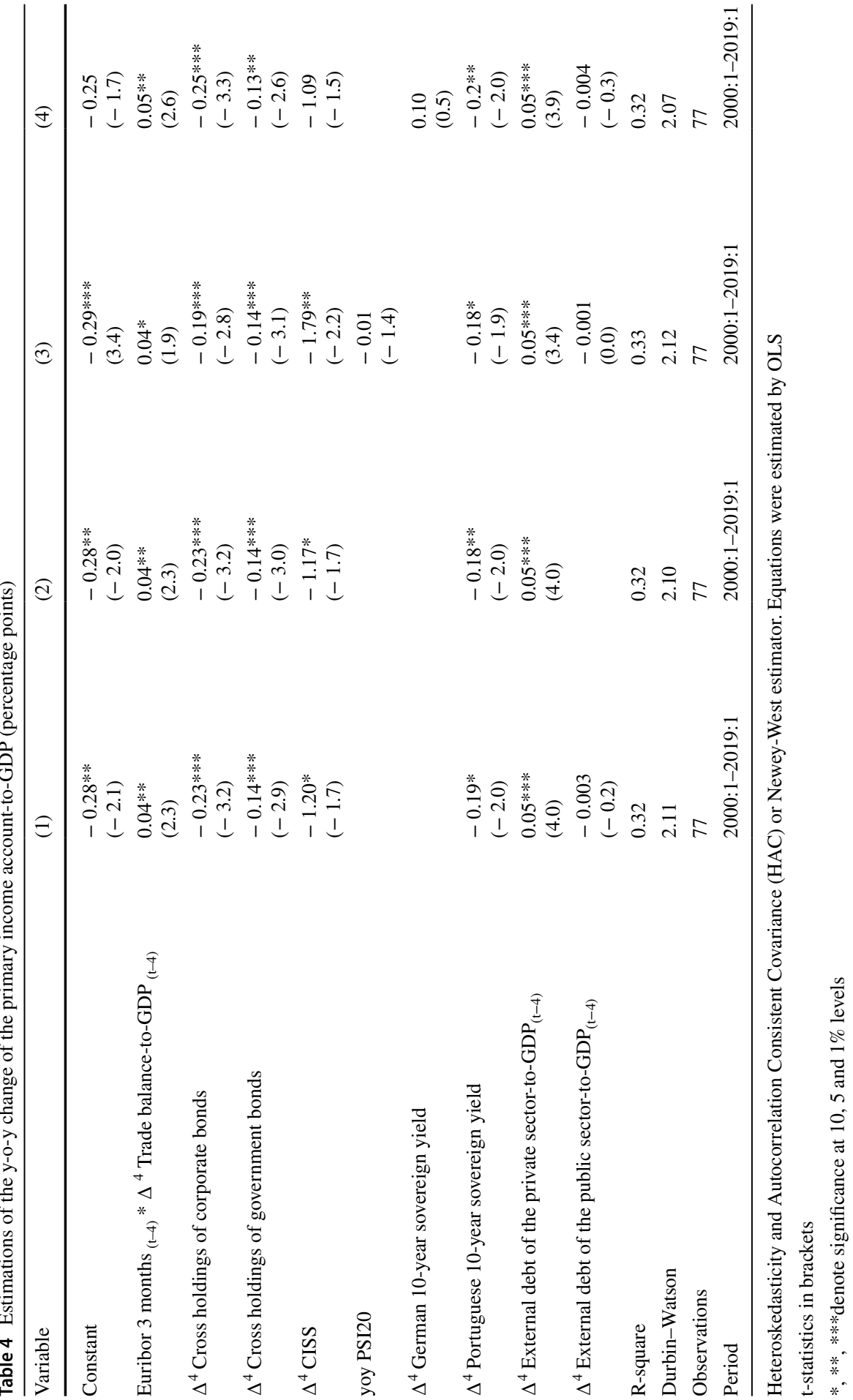




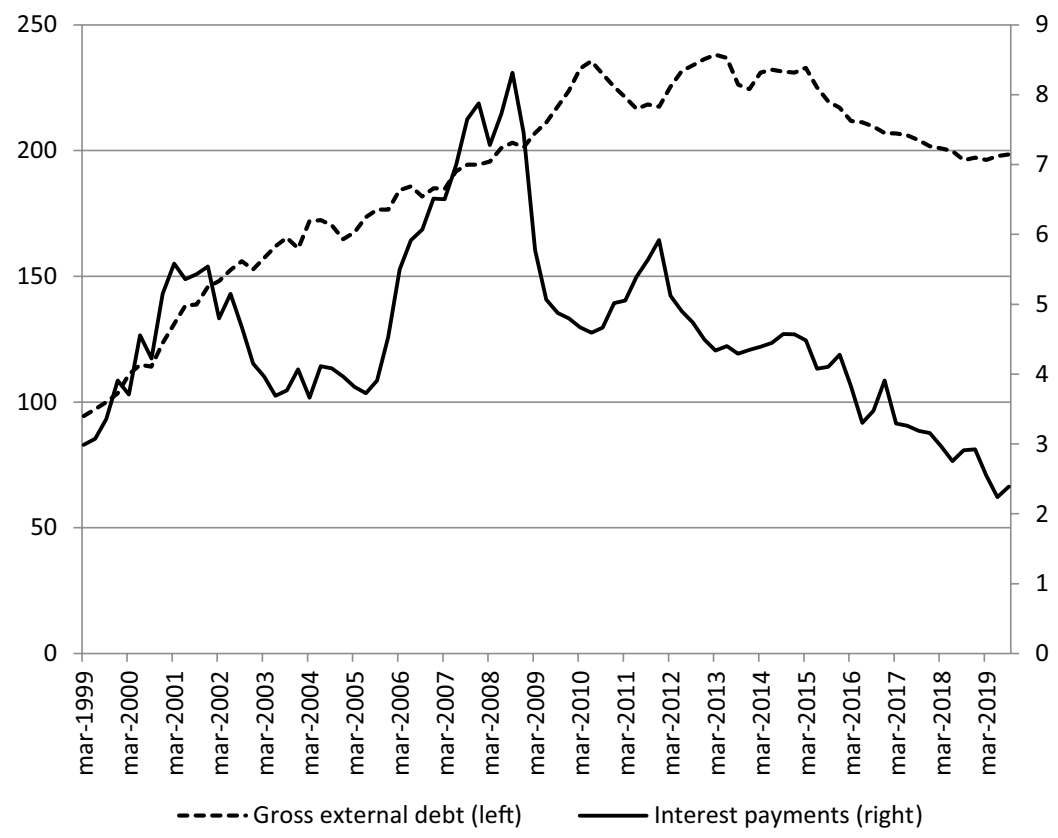

Fig. 5 Gross external debt and interest payments (percentage of GDP). Source: $B d P$ Banco de Portugal (2020), INE Statistics Portugal and own calculations (2020)

External debt did not substantially and positively affect the inputs of the production function. Indeed, there was no positive impact on the economic growth rate to offset the interest rate underlying the Portuguese external debt. The rise in external debt did not lead to a structural deterioration of the primary income account due to the reduction of interest rates level in the euro area. The increase in net external debt had the aim of funding the trade balance deficit and the negative primary income account.

Only some channels of transmission were positively and significantly affected by external debt: the private and public external debt increased the public investment in volume, and private external debt damaged private investment in volume per person employed. The private saving, real GDP per person employed, private GVA in volume per person employed, total factor productivity and primary income account were not positively and significantly affected by external debt.

Financial integration, whose proxies are the cross border funding of corporate or sovereign bonds in the euro area, affected negatively the primary income account, private saving, public investment and real GDP per person employed. Periods of financial integration (financial fragmentation) made easier (more difficult) to fund the current account deficit and domestic demand. 


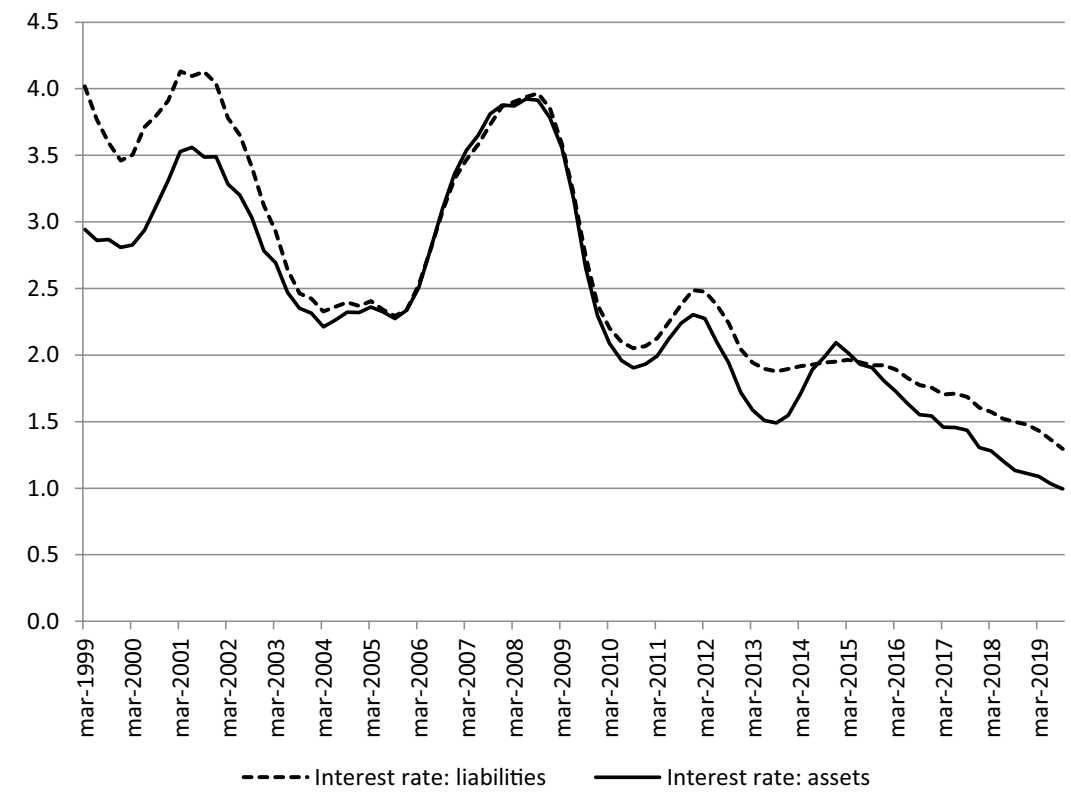

Fig. 6 Interest rates of external debt and external assets (percentage). Source: $B d P$ Banco de Portugal (2020), INE Statistics Portugal and own calculations (2020)

Financial stress in Europe seems to have affected negatively primary income account, total factor productivity and private saving. The results suggest that financial instability widened interest rate spreads among countries. Portugal was negatively impacted due to high net external debt-to-GDP.

Regarding policy implications, it would be advisable to reduce external debt through a positive current account, to shift debt instruments in favor of equity instruments (Faria et al. 2007), as well as to assign external debt to tradable sectors that will obtain a higher return on investments. This means a structural change in the private sector production function. If the interest rates rise, the high external debtto-GDP ratio determines a structural deterioration on the primary income account. It makes it more difficult to achieve the equilibrium of the balance of payments.

Regarding some possible limitations, external debt may affect economic growth by other channels that were not identified by the existing literature. Additionally, the private sector is very heterogeneous. Therefore, the split between the tradable and non-tradable sectors would be useful. However, currently there are no quarterly/ yearly data that split tradable and non-tradable sectors for a wide range of economic time series.

Future research may benefit of a larger period of analysis. After the end of the zero lower bound and unconventional monetary instruments, and excluding the 


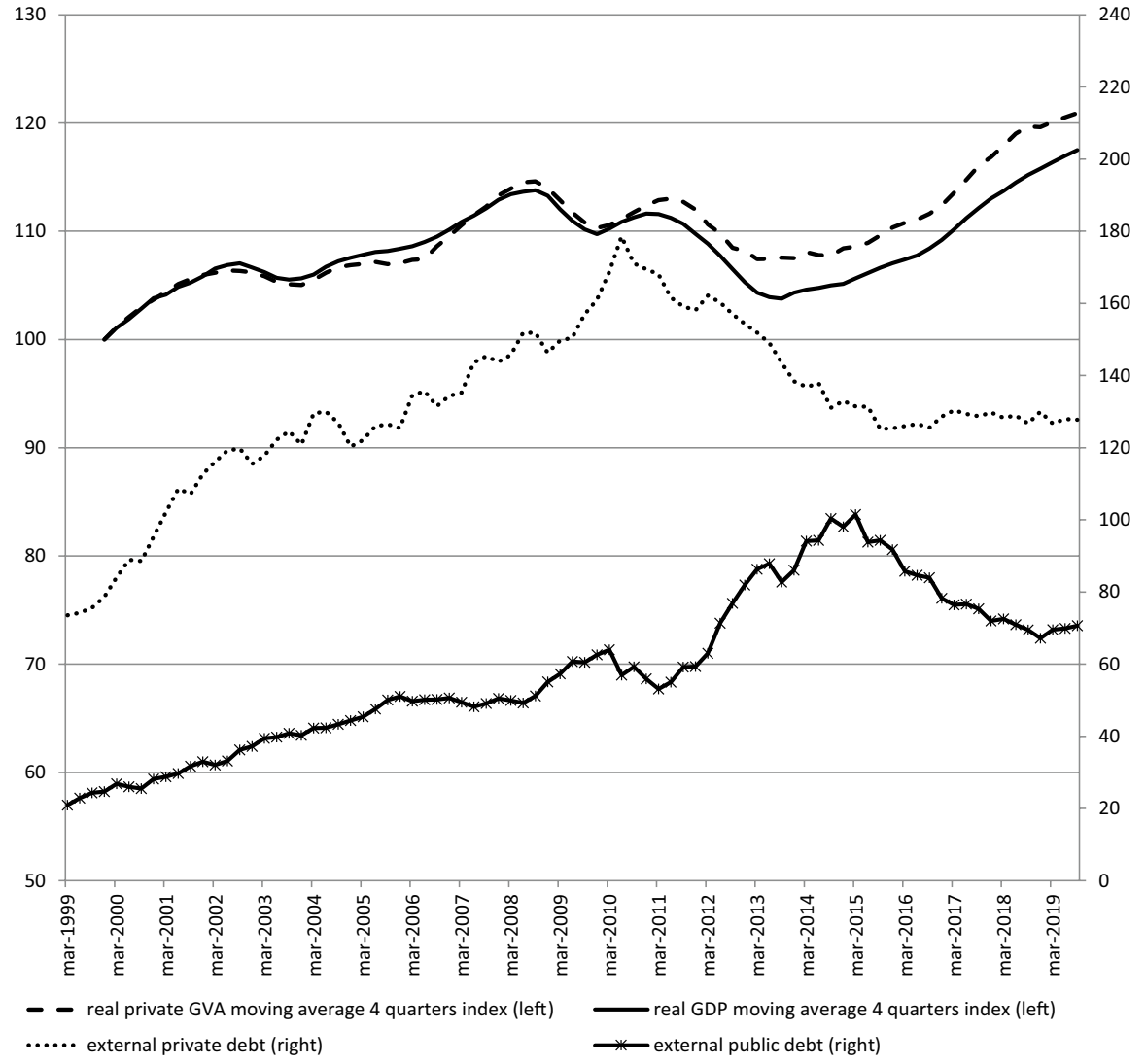

Fig. 7 Gross value added in volume (private sector), real GDP (total economy) and gross external debt (private sector and public sector). Index based on moving average 4 quarters (left), and percentage of GDP (right). Source: BdP Banco de Portugal (2020), INE Statistics Portugal and own calculations (2020)

economic effects of the Covid-19 pandemic, it will be interesting to assess the effect of these contexts on the external debt of small open economies.

\section{Compliance with ethical standards}

Conflict of interest The corresponding author states that there is no conflict of interest.

\section{References}

Afonso, A., \& Jalles, J. T. (2013). Growth and productivity: The role of government debt. International Review of Economics and Finance, 1, 384-407. 
Afonso, A., \& Silva, J. (2017). Determinants of nonresident government debt ownership. Applied Economics Letters, 1, 107-112.

Banco de Portugal. (2020). BP stat database. Downloaded from https://bpstat.bportugal.pt/dados/explo rer. Accessed 26 Jan 2020.

Cieślik, A. (2020). Determinants of foreign direct investment from OECD countries in Poland. Eurasian Economic Review, 10, 9-25. https://doi.org/10.1007/s40822-019-00136-y.

Checherita-Westphal, C., \& Rother, P. (2012). The impact of high government debt on economic growth and its channels: An empirical investigation for the euro area. European Economic Review, 1, 1392-1405.

Faria, A., Mauro, P., Lane, P. R., \& Milesi-Ferretti, G. M. (2007). The shifting composition of external liabilities. Journal of the European Economic Association, 5(2-3), 480-490. https://doi. org/10.1162/jeea.2007.5.2-3.480.

Gros, D. (2011). External versus domestic debt in the euro crisis. CEPS Policy Brief No. 243. Available at SSRN: https://ssrn.com/abstract=1898656.

Instituto Nacional de Estatística. (2020). The Portuguese National Accounts database, European System Accounts 2010. Downloaded from https://www.ine.pt/xportal/xmain?xpid=INE\&xpgid=ine_cnaci onais\&xlang=en. Accessed 28 Jan 2020.

Pattillo, C., Poirson, H., \& Ricci, L. A. (2011). External debt and growth. Review of Economics and Institutions.

Reinhart, C. M., \& Rogoff, K. S. (2010). Growth in a time of debt. American Economic Review, 1, 573-578.

Reis, R. (2013). The Portuguese slump and crash and the euro crisis. Brookings Papers on Economic Activity, 143-193.

Reis, R. (2016). Can the central bank alleviate fiscal burdens? NBER Working Paper No. 23014.

Schclarek, A. (2004). Debt and economic growth in developing and industrial countries.

Toktaş, Y., Altiner, A., \& Bozkurt, E. (2019). The relationship between Turkey's foreign debt and economic growth: an asymmetric causality analysis. Applied Economics, 51(26), 2807-2817. https:// doi.org/10.1080/00036846.2018.1558360.

Publisher's Note Springer Nature remains neutral with regard to jurisdictional claims in published maps and institutional affiliations. 